\title{
Who Is in Charge? Social Inequality in Different Fields of Volunteering
}

\author{
Michael Meyer ${ }^{1} \cdot$ Paul Rameder $^{1}$ (B)
}

Accepted: 31 December 2020/Published online: 28 January 2021

(C) The Author(s) 2021

\begin{abstract}
Volunteering in civil society organizations (CSOs) is sometimes idealized as welcoming arena for everybody. Prior research, however, has shown that participation in volunteer work depends on gender, wealth, education, and social networks, suggesting that CSOs are not in fact open to everyone. Inequality within different fields of volunteering combined with the factors that put actors into more powerful positions has rarely been scrutinized. Besides identifying the characteristics and resources relevant for promotion, we primarily investigate how these patterns differ between four subfields: politics, social services, religion, and sports. We analyzed a large database created from the Austrian micro-census. The findings reveal significant relations between the actors' gender, their occupational and educational status, and their hierarchical positions in CSOs within each of the subfields. Our results indicate that the extent to which social inequality spills over to volunteering depends on field characteristics: In the fields of sports and politics, occupational status plays a major role, while in the fields of religion and social services, educational status is more important. We explain these differences through organizational and individual factors that characterize these social fields.
\end{abstract}

Keywords Civil society organizations (CSOs) - Fields of volunteering · Hierarchy in volunteering · Inequality

Paul Rameder

paul.rameder@wu.ac.at

1 Institute for Nonprofit Management, Vienna University of Economics and Business, Welthandelsplatz 1, 1020 Vienna, Austria

\section{Introduction}

With respect to volunteering in civil society organizations (CSOs), we sometimes assume that everyone will be able to find their niche and be able to act according to their competencies and desires (e.g., Stebbins 2009). Many see volunteering as a tool that contributes to social integration (of immigrants, see Handy and Greenspan 2009; Hapke 2009, 329; of retired people, see Moen et al. 2000). Naturally, volunteers fulfill many roles that help CSOs to serve the public good, but volunteering itself does not automatically foster integration and inclusion. A large body of research shows that volunteering is not only determined by individuals' willingness to volunteer, but also by their resources and individual circumstances (Broese van Groenou and van Tilburg 2012; Institute for Volunteering Research 2004; Shachar 2014; Smith 1994; Tang 2006; Wilson 2000). While most research has investigated the factors that determine whether someone volunteers, fewer studies have explored the individual factors determining within which fields volunteering happens (e.g., van Ingen and Dekker 2010; Hustinx 2007; Hustinx and Lammertyn 2003), or the organizational factors that attract and select volunteers (Hustinx and Handy 2009; Fisher and Ackerman 1998).

Yet all of these studies tell us little about which volunteers reach senior/managerial positions, i.e., supervisory and board positions. As volunteering is hierarchically stratified, some positions involve more authority over people and budgets, while others only carry out narrow tasks assigned to them by others (Musick and Wilson 2008). Research that explains this stratification is scarce, and its field-specific reasons have not been investigated at all. Overall, there are various reasons why the stratification of volunteers within voluntary organizations deserves more 
attention in inequality research. First, because it indicates that different social groups have different opportunities to actualize their interests in volunteering and thus in society. Second, before recommending volunteering as a measure to fight inequality (for integration of the unemployed, immigrants, or the elderly), more research has to be conducted on the effects of volunteering on inequality. Research on membership points toward adverse effects: "privileged citizens-who do not need the benefits of associational involvement in the first place-show the highest membership rates and occupy the most important positions within associations" (Van Ingen 2009, 144). Third, the need to recruit the best volunteers is often in conflict with CSOs' goal to integrate disadvantaged groups. Thus, both in management and governance a conflict arises between stakeholder representation, accessibility, and the particular skills demanded from volunteers. Finally, volunteering is not a homogenous field. We therefore suggest a fieldspecific approach to disclose the different rules that forward inequality in different fields of volunteering.

This article is structured as follows: First, we summarize prior research and elaborate on social mechanisms that explain hierarchical stratification in volunteering. We then explain the unequal access to senior/managerial positions in different fields of volunteering, i.e., politics, religion, sports, and social services. Based on field-specific characteristics of volunteers (voluntary workforce), paid workforce and organizations, we hypothesize field-specific spillover-effects for gender, occupational and educational status. We then describe the context, data and methods of our study. Finally, we present and discuss our results; how gender together with occupational and educational status contribute to the attaining of senior/managerial positions in different fields of volunteering.

\section{Literature Review}

Previous research has concentrated on determinants that predict voluntary engagement. Authors use different concepts to bundle the various socioeconomic and demographic variables. Educational level is one of the factors that appears in most studies as a "consistent predictor of volunteering" (Wilson 2000, 219; Wilson 2012, 185). Only rarely do we find research casting doubt on the influence of education on voluntary engagement, since it is difficult to disentangle from social background (e.g., Egerton 2002). Income and occupational status also correlate positively with volunteering (Pearce 1993; Tang 2006; Wilson 2012, 187). As far back as a century ago, Max Weber (1921/ 1980, 170) was describing such resources as prerequisites for those volunteering at the executive level (Honoratioren, i.e., notables); they should be wealthy, and should have a high reputation to get elected and gain the trust of the other members (Weber 1921/1980, 1978, 290). Occupations of the day that were considered appropriate included rentiers, part-time entrepreneurs, and other self-employed positions that bestowed plenty of wealth and spare time.

More recently, Musick and Wilson (2008) have addressed the hierarchy in volunteering. Results of their analyses suggest that neither race, employment status, nor church attendance have a bearing on a volunteer's hierarchical position. Yet the higher ranks are more likely to be filled by older people, as well as males, professionals, managers, and persons with higher education. In this respect, the voluntary sector seems to therefore mirror paid work (Webb and Abzug 2008). Volunteering, however, is not a monolithic endeavor. Rather, it is one that occurs in diverse social fields and is embedded in various social worlds, which are in turn composed of characteristic groups, events, routines, practices, and organizations (Stebbins 1996; Unruh 1979, 1980).

Aside from volunteers' motives, social transmission mechanisms link individual characteristics with roles and positions within the respective fields. First, direct relations between resources and the field-positions can be explained by either spillover- or contrast-effects, which will guide our hypotheses. Prior research strongly supports the spillover hypothesis. Second, ascribed characteristics (e.g., the social construction of gender, age, and race) also contribute directly to an actor's position within the organization. Social learning, role modeling, and value internalization influence the general inclination toward volunteering and toward senior/managerial positions. Mechanisms of homophily, which denotes the attractiveness of similarities, could also affect the selection of volunteers (McPherson et al. 2001; Rotolo and Wharton 2003).

The contrast-effect hypothesis postulates a reversed stratification in the field of volunteering as compared to other fields. "Volunteer work offers itself as an alternative stratification system in which the powerless can gain authority and exercise power" (Rotolo and Wilson 2007, 559f.). Yet the spillover-effect hypothesis suggests the opposite relation as "generative processes of inequality mutually reinforce or at least facilitate each other in different fields of activity" (Diewald and Faist 2011). Stratification in volunteer work mirrors and reproduces the social hierarchy in paid work. Rotolo and Wilson (2007) confirm the spillover hypothesis with respect to gender. As recruiting and organizing are becoming similar in volunteering and paid work, men are overrepresented on CSOs' boards and committees. Moreover, positions in paid work have different consequences for male and female volunteering. "Although women are less likely than men to supervise others [in the field of paid work], being a supervisor promotes women's volunteering but not men's" 
(Marshall and Taniguchi 2012, 228). Spillover- and contrast-effects are both based upon and moderated by at least three underlying mechanisms, namely accumulative advantage, signaling, and homophily.

Accumulative advantage, also known as the Matthew Effect, is the phenomenon by which the rich get richer and the poor get poorer (e.g., Merton 1968). Those already privileged in paid work will capture superior positions in volunteering (Brady 2003; Rigney 2010). On the one hand, volunteering requires specific knowledge, education, social capital, and reputation, but also financial security. On the other hand, volunteering in turn facilitates the augmentation of these same resources (Ruiter and De Graaf 2009; Handy and Mook 2011, 413). The reputational gains from voluntary board and committee membership are significant (Handy et al. 2010; Wilson and Musick 1997a, 709).

Board- and committee-volunteering contributes particularly to a mutual development of prestige for both volunteers and organizations: Enhancing prestige "is a highly sought after by-product of volunteering. Unlike donations, which anyone can make, board seats are extremely limited, thereby creating an aura of selectivity" (Handy and Mook 2011, 414). The more elitist and prestigious the organization, the more it bestows prestige on its volunteers (Ostrower 2002). By contrast, members of lower social classes benefit much less from their voluntary engagement (Ruiter and De Graaf 2009).

Likewise, signaling contributes to spillover-effects. Labor markets use single characteristics of actors to evaluate skills, competencies, or traits, e.g., educational degrees as indicators for cognitive skills (Spence 1973). Therefore CSOs tend to recruit better educated individuals for board positions (Rotolo and Wilson 2007, 563; Nisbett and Wilson 1977; Wetzel et al. 1981). Similarly, volunteering signals an individual's specific traits and competencies to the labor market and other social fields. These signals are not only helpful for re-entry into job markets (e.g., after parental leaves) or for career advancement, but are also supportive for students' admission to universities (Handy et al. 2010).

Individuals prefer to interact with others who share a similar ethnic heritage and social status, hence also sharing experiences and tastes (Tolsma et al. 2009, 287). The pervasiveness of homophily, the degree of similarity between interacting individuals, has gained substantial support in a wide array of studies (Blau 1977; Lazarsfeld and Merton 1954; Melamed et al. 2020). Gender- and minority-biased hierarchies were borne of such observations (e.g., Tharenou and Conroy 1994; Pfeffer et al. 1995; Landau 1995; Haberfeld 1992). Recent studies have shown that homophily plays a role in religious volunteering (Galen et al. 2015; Merino 2012, 2013), yet less in community engagement (Tolsma et al. 2009).
Empirical findings indicate that a volunteer's position within an organization depends on his/her individualistic characteristics, pointing toward a reproduction of social inequality. However, prior research has not investigated differences between fields of volunteering, like sports, religion, or social services.

\section{Theory}

Inequalities such as these are the focus of Pierre Bourdieu's theory of practice (see Macmillan 2013; Quinn 2020 for applications of this theory for volunteering). It rests on four core concepts (Bourdieu 1977, 1984, 1986b): (1) social fields, (2) rules of the game, i.e., structures of the field, (3) capital, i.e., cultural, social and economic resources of actors, and (4) the actor's habitus. An actor's capital relates to his/her position in the fields of volunteering. In our study and according to Bourdieu, social fields are playgrounds or battlefields with particular rules. According to them, actors try to maintain or improve their positions through their field-relevant capital and a patterned set of practices. Though we will not strictly operationalize this theory, our research has been inspired by its analytical potential, in particular by Bourdieu's notion of social fields. Unlike institutional fields, policy fields, or strategic action fields (for a comparison of field concepts, see Zietsma et al. 2017), Bourdieu's fields explicitly explain stratification, and introduce economic, social, and cultural capital in its basic, institutionalized or incorporated (habitualized) form to dynamically explain actors' positions and status.

Individuals follow a particular logic of practice and acquire resources (Bourdieu 1986a) that might also be of value in other fields. Practices follow the rules and structures of the field, and users of which simultaneously contribute to those rules and structures, either by reinforcing or eroding them. Symbolic capital is the prestige or status that derives from previous practice. As with occupational prestige or educational status, it is a prerequisite for many board and committee positions, and these positions again contribute to an actor's reputation. Field-specific structures, however, determine which combinations of resources yield reputation. In terms of Bourdieu's economie des biens symbolique (Bourdieu 1998, 92ff.), the gains of prestige are not arbitrary but rather depend on time and amount of prestige invested.

Although individual motives for voluntary work (e.g., VFI, ${ }^{1}$ Clary et al. 1998) involve self-oriented aspects (career, skills, social networks), a recent meta-analysis of 48 studies shows that altruistic and humanitarian concerns are dominant in all fields (Chacón et al. 2017). This is not surprising, since it would not serve actors well to admit that

\footnotetext{
${ }^{1}$ Voluntary Function Inventory.
} 
their voluntary engagement is motivated by reputational gains (Small 2009). For this form of delusion, Bourdieu uses the notion of illusio (Bourdieu 1998, 76ff.). Investments in volunteering will yield reputational gains only if the economic nature of transactions remains hidden: "This sort of double-consciousness, which is undoubtedly common to all social agents who participate both in the economic universe and the anti-economic sub-universes (we might think of all party activists and all "volunteer workers'), is at the basis of a very great (partial) lucidity ..." (Bourdieu 1998, 113). Hence, altruism is still the dominant illusio in the fields of volunteering, though it has grown paler in some fields such as sports and politics (e.g., Schlesinger and Gubler 2016) and has developed toward reflexive volunteering (Hustinx 2010; Hustinx and Lammertyn 2003) that becomes part of identity work (Grönlund 2011). Perhaps self-actualization is about to replace altruism as the field-dominant illusio.

Bourdieu's framework suggests a reinterpretation of the effects described above. A contrast effect, for instance, is based on rules that differ between social fields, whereas a spillover effect suggests that the capital (particularly symbolic capital) advantageous in the first field also promotes an actor's status in the second. Signaling is either based on specific forms of capital that are easily visible, or on symbolic capital and the impact of reputation. The Matthew effect describes how a previous capital endowment acquired contributes to a superior position and privileges that further enhance this endowment in different fields, such as volunteering. Finally, homophily results from field rules that promote actors with a similar habitus.

\section{Hypotheses}

Voluntary organizations operate in particular subfields (e.g., see ICNPO, Salamon and Anheier 1996). They deliver products and services, provide public advocacy and lobbying, and they participate in building communities and social capital (James and Rose-Ackermann 1986). In this respect, some fields are closer to business, some fields are closer to politics, and some fields are closer to communities. Therefore, we selected four distinct fields of volunteering: sports, politics, religion, social services. Table 1 summarizes the characteristics of these fields. These fields represent some very diverse functions of civil society.

There are additional reasons for our selection. First, these four fields cover the vast majority of volunteering in Austria- $71.4 \%$ of all volunteers work in one of these four fields. Second, they encompass various forms of CSOs, each differing in terms of their size, age, and spatial distribution: $18 \%$ of all Austrian CSOs operate in the field of sports, $7.6 \%$ in social services, $3.4 \%$ in politics, and $1.6 \%$ in religion. The median age of the CSOs varies between 13 years in the field of politics and 19 years in the field of religion. In politics, religion, and social services, CSOs are mainly located in urban areas, whereas sports CSOs are mainly located in rural areas. Third, in politics and social services, the share of paid workforce is much higher than in sports and religion (Neumayr et al. 2017). Again, the organizational size in politics and social services points toward stronger spillover-effects than those found in sports and religion.

Fourth, the fields also differ in their voluntary workforce characteristics. Volunteers in sports, religion, and politics typically live in rural neighborhoods, whereas volunteering in social services typically occurs in urban environments. The gender ratio within the voluntary workforce ranges from $66.4 \%$ females in the field of religion and $55.3 \%$ in social services, down to $30.7 \%$ in sports and $29.1 \%$ in politics. The average age of volunteers ranges from 41.17 years in sports to 49.70 in social services. In politics, $83.8 \%$ of the volunteers economically active population. This ratio falls to $76.9 \%$ in sports, $61.0 \%$ in religion, and $53.0 \%$ in social services. These characteristics point in particular to a stronger effect of gender in sports and politics.

Fifth and finally, the four fields differ considerably in the degree of hierarchization of the volunteers (Diewald and Faist 2011; Therborn 2006), namely the proportion of volunteers in senior/managerial positions. In religion, only $16.7 \%$ of the volunteers are in senior/managerial positions. In politics, this ratio is $34.4 \%$, while sports $(22.2 \%)$ and social services $(21.0 \%)$ lie between these extremes. A closer look reveals more gender inequality: In sports, the overall gender ratio of $30.7 \%$ drops down to $16.7 \%$ for senior/managerial positions. The same pattern holds for religion: While females represent $66.4 \%$ of all volunteers in this field, they represent only $55.9 \%$ of all senior/managerial positions. We assume that the scarcity of volunteersenior/managerial positions in religion will increase the relevance of education in attaining such roles.

In some fields, CSOs are larger and more business-like; in other fields, they are smaller, more grassroots and socialmovement orientated. Larger formal CSOs, employing larger numbers of paid workforce, will likely display a similar inequality pattern to the field of paid work. This may be less prevalent in smaller organizations with higher proportions of volunteers. Likewise, the overall share of females in a particular field of volunteering is likely to positively affect females' access to higher ranks. Based on these assumptions, we formulate hypotheses for fieldspecific spillover-effects, specifying which resources we assume to contribute to inequality in volunteering.

Figure 1 gives an overview of the factors that constitute field-specific relations between occupational and educational status, gender, age, and senior/managerial positions. 
Table 1 Characteristics of the four fields of volunteering

\begin{tabular}{|c|c|c|c|c|}
\hline \multirow[t]{2}{*}{ Characteristics } & \multicolumn{4}{|c|}{ Fields of volunteering } \\
\hline & Sports & Politics & Religion & Social services \\
\hline \multicolumn{5}{|c|}{ Voluntary \& paid workforce characteristics } \\
\hline $\begin{array}{l}\% \text { of total Austrian } \\
\text { population }{ }^{\mathrm{a}} \text { (aged over } \\
15)\end{array}$ & $6.9 \%(474,699)$ & $3.5 \%(242,178)$ & $6.2 \%(428,532)$ & $3.3 \%(227,916)$ \\
\hline $\begin{array}{l}\% \text { of total Austrian } \\
\text { volunteers } \\
(N=1,925,392 ; \\
27.9 \%)\end{array}$ & $24.7 \%$ & $12.6 \%$ & $22.3 \%$ & $11.8 \%$ \\
\hline $\begin{array}{l}\text { Females within } \\
\text { voluntary workforce }^{\mathrm{a}}\end{array}$ & $30.7 \%$ & $29.1 \%$ & $66.4 \%$ & $55.3 \%$ \\
\hline Age of volunteers ${ }^{b}$ & $41.17(13.88)$ & $44.78(12.88)$ & $47.58(15.05)$ & $49.70(16.26)$ \\
\hline $\begin{array}{l}\text { Share of economically } \\
\text { active volunteers }\end{array}$ & $76.9 \%$ & $83.8 \%$ & $61.0 \%$ & $53.0 \%$ \\
\hline $\begin{array}{l}\text { Share of volunteers with } \\
\text { a senior/managerial } \\
\text { position }^{\text {a }} \text { (of the total } \\
\text { voluntary workforce in } \\
\text { the field) }\end{array}$ & $22.2 \%$ & $34.4 \%$ & $16.7 \%$ & $21.0 \%$ \\
\hline $\begin{array}{l}\text { Females in } \\
\text { senior/managerial } \\
\text { positions }^{\mathrm{a}}\end{array}$ & $16.7 \%$ & $19.9 \%$ & $55.9 \%$ & $41.6 \%$ \\
\hline $\begin{array}{l}\text { Spatial distribution of } \\
\text { volunteers }{ }^{\mathrm{a}} \text { : urban }\end{array}$ & $20.3 \%$ & $22.6 \%$ & $21.6 \%$ & $29.2 \%$ \\
\hline $\begin{array}{l}\text { Spatial distribution of } \\
\text { volunteers }{ }^{\mathrm{a}} \text { : rural }\end{array}$ & $49.5 \%$ & $53.5 \%$ & $51.4 \%$ & $41.7 \%$ \\
\hline $\begin{array}{l}\text { Approximate number of } \\
\text { paid employees }\end{array}$ & 5000 & 45,000 & $\mathrm{~N} / \mathrm{N}$ & 150,000 \\
\hline \multicolumn{5}{|c|}{ Organizational characteristics } \\
\hline $\begin{array}{l}\text { Type of CSOs formal } \\
\text { volunteering takes } \\
\text { place }^{\mathrm{d}}\end{array}$ & $\begin{array}{l}\text { Sports } \\
\text { organizations } \\
\text { and } \\
\text { associations }\end{array}$ & $\begin{array}{l}\text { Political parties; municipal } \\
\text { government; human rights } \\
\text { organizations; development } \\
\text { organizations, trade unions; } \\
\text { professional organizations }\end{array}$ & $\begin{array}{l}\text { Congregations; church } \\
\text { councils; religious } \\
\text { associations; } \\
\text { religious youth/ } \\
\text { senior groups/centers }\end{array}$ & $\begin{array}{l}\text { Social services organizations (e.g., } \\
\text { Caritas, Red Cross), disability } \\
\text { associations; self-help } \\
\text { organizations; youth centers; } \\
\text { senior centers; palliative and } \\
\text { hospice care; hospitals; nursing } \\
\text { and care homes }\end{array}$ \\
\hline$\%$ of all associations ${ }^{\mathrm{e}}$ & $\begin{array}{l}18.8 \% \\
\text { (constant) }\end{array}$ & $3.4 \%$ (increasing) & $1.6 \%$ (constant) & $7.6 \%$ (increasing) \\
\hline $\begin{array}{c}\text { Median age of } \\
\text { organization }^{\mathrm{e}}\end{array}$ & $18 \mathrm{y}$ & $13 \mathrm{y}$ & $19 \mathrm{y}$ & $15 \mathrm{y}$ \\
\hline Spatial distribution $^{\mathrm{e}}$ & Mainly rural & Mainly urban & Mainly urban & Mainly urban \\
\hline
\end{tabular}

${ }^{\mathrm{a}}$ Source: Austria Micro-census 2006/Q4

${ }^{\mathrm{b}}$ Average age of the Austrian population older than 15 years: 46.07 (18.70)

${ }^{c}$ Source: Neumayr et al. (2017)

${ }^{d}$ Source: Federal Ministry of Labor Social Affairs and Consumer Protection 2015

${ }^{\mathrm{e}}$ Austrian Register of Associations

We assume that three factors are particularly relevant for the strength of spillover-effects: (a) organizational characteristics, (b) voluntary workforce characteristics, and (c) the share of senior and managerial positions in the field, which we will then condense to field-specific assumptions: 


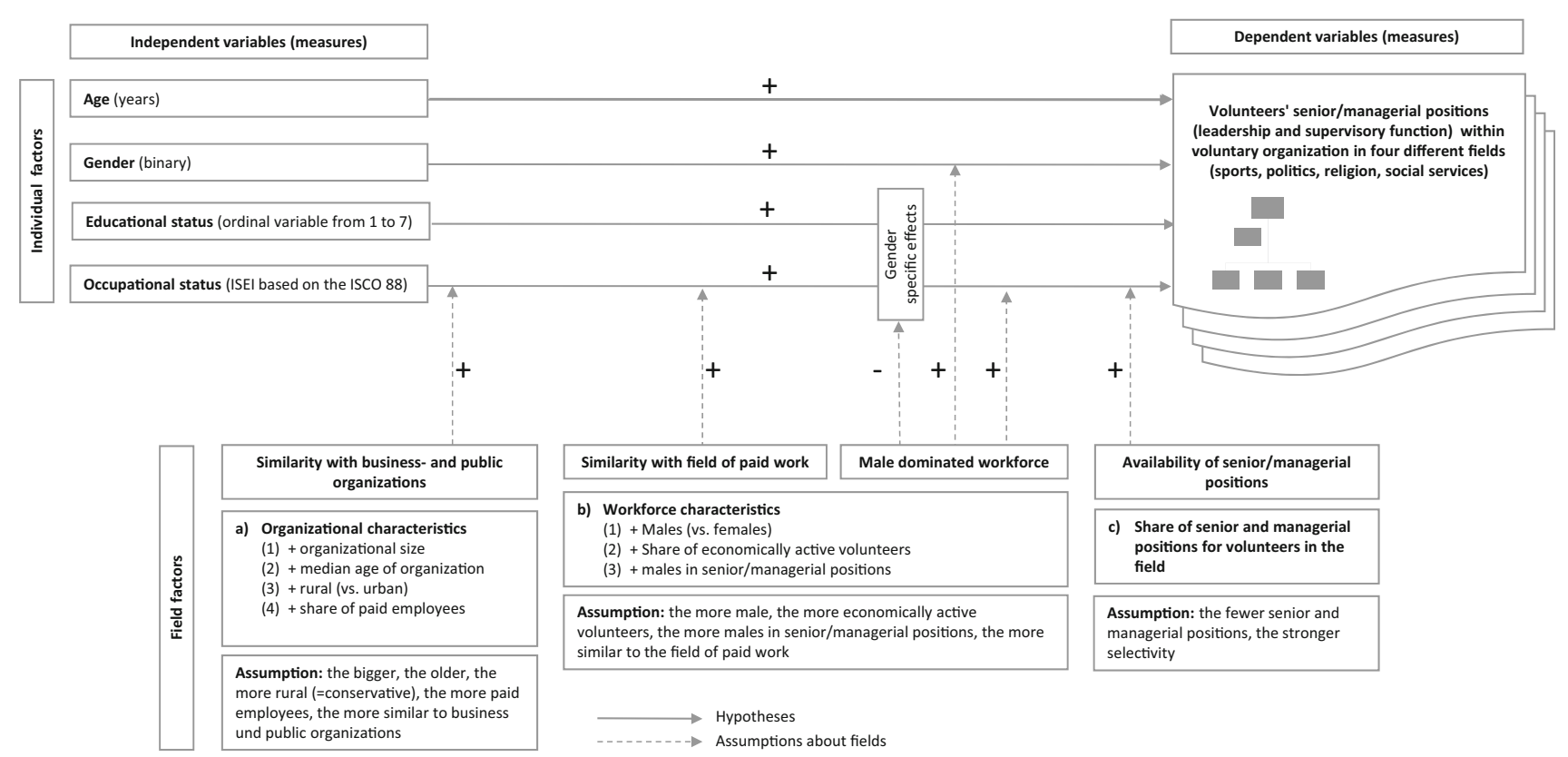

Fig. 1 Variables, measures, and assumptions

(a) We expect stronger spillover-effects in fields with rather big organizations and a higher share of paid workforce.

(b) We expect stronger spillover-effects in male-dominated fields with a higher percentage of economically active volunteers in the voluntary workforce, mainly for the same reasons.

(c) We expect stronger spillover-effects in fields with fewer senior and managerial positions due to a stronger selectivity, and thus potential reputational advantages in these fields.

Generally, we assume that stratification in the field of volunteering mirrors societal stratification; primarily, due to an occupational spillover-effect:

H1 $_{1}$ A higher occupational status in paid work contributes positively to gaining a senior/managerial position in volunteering.

We also assume that education and gender also relate positively with senior/managerial positions in volunteering.

$\mathbf{H}_{2}$ Educational level relates positively with senior/managerial positions in volunteering.

$\mathbf{H}_{3}$ Male gender relates positively with senior/managerial positions in volunteering.

Given this effect, that females are less likely to gain senior/managerial positions, we suppose that females can only compensate for it with an extra endowment of education and occupational prestige, and that they do not advance in hierarchy through seniority alone.
$\mathbf{H}_{4}$ In comparison with that of men, the number of females in senior/managerial positions correlates more strongly with occupational and educational status than with age.

We then formulate field-specific hypotheses. The spillover-effects outlined above in assumptions (a) to (c) strengthen or weaken our hypotheses 1-4 for our fields, yielding the following hypotheses (see Table 2):

Field-specific $\mathbf{H}_{\mathbf{1}}$ The higher the similarity between a specific field of volunteering and the field of paid work, the stronger the occupational spillover-effects will be $\left(\mathrm{H}_{1-\text { poli- }}\right.$ tics, $\mathrm{H}_{1 \text {-social }}$ ).

Field-specific $\mathbf{H}_{2}$ For sports and religion, we assume educational effects $\left(\mathrm{H}_{2 \text {-sport }}, \mathrm{H}_{2 \text {-religion }}\right)$, which also work in politics and social services $\left(\mathrm{H}_{2 \text {-politics }}, \mathrm{H}_{2 \text {-social }}\right)$, in addition to the occupational spillover-effect.

Field-specific $\mathbf{H}_{3}$ The higher the male dominance in a field of volunteering, the stronger its effect on achieving senior/managerial positions, which should be true for sports and politics $\left(\mathrm{H}_{3 \text {-sports, }} \mathrm{H}_{3 \text {-politics }}\right)$.

Field-specific $\mathbf{H}_{\mathbf{4}}$ The higher the female dominance in a field of volunteering, the more females will need a superior occupational or educational status to advance to senior/managerial positions in that field, which should be true for religion and social services $\left(\mathrm{H}_{4 \text {-religion, }} \mathrm{H}_{4 \text {-social }}\right)$. 
Table 2 Overall and fieldspecific hypotheses of spillovereffects for achieving senior/managerial positions in volunteering

\begin{tabular}{llllll}
\hline Hypothesis & \multicolumn{3}{l}{ Fields of volunteering } & & \\
\cline { 2 - 6 } & Overall & Sports & Politics & Religion & Social services \\
\hline H1: Occupational status & + & No effect & $+(\mathrm{abc})$ & No effect & $+(\mathrm{abc})$ \\
H2: Educational status & + & $+(\mathrm{c})$ & $+(\mathrm{abc})$ & $+(\mathrm{c})$ & $+(\mathrm{abc})$ \\
H3: Gender (male) & + & $+(\mathrm{b})$ & $+(\mathrm{b})$ & No effect $(\mathrm{b})$ & No effect (c) \\
H4: Gender-specific effects & + & No effect $(\mathrm{abc})$ & No effect $(\mathrm{abc})$ & $+(\mathrm{abc})$ & $+(\mathrm{abc})$ \\
\hline
\end{tabular}

(a) Organizational characteristics

(b) Voluntary workforce characteristics

(c) The share of senior and managerial positions in the field

\section{Methods}

Questionnaire. Data was collected by Statistik Austria in the 2006 micro-census on volunteering. Participation in the questionnaire (CATI method) was optional and a supplement to the general micro-census questionnaire. A randomized share of $63 \%$ (26,128 people) of the total microcensus sample were invited to take part in the survey. A total of 11,661 people agreed to complete the questionnaire. A particular strength of our data lies in the differentiated measurement of respondents' paid jobs, employment status, and occupational characteristics. Together with the variables on volunteering, this allows for a thorough testing of the spillover hypothesis. Although the data was collected more than a decade ago, more recent surveys suggest that there have been no significant changes in the fields of volunteering in Austria that might sway our major findings (Federal Ministry of Labor Social Affairs and Consumer Protection 2015).

Data. In 2012, 28\% of all Austrians older than 15 were engaged in formal volunteering, with the engagement of more men $(32 \%)$ than women $(24 \%)$ (Federal Ministry of Labor Social Affairs and Consumer Protection 2015). Within Europe, the Austrian rate is in the middle, between Sweden at the top (54\%), and Portugal and Ukraine at the bottom (12\%) (Hodgkinson 2003). Austria's voluntary sector has been influenced by the two-party system established after World II, the relevance of the (Catholic) church, the federal structure and the third-sector regime (Neumayr et al. 2007, 2017). Due to the corporatist particularities of the welfare state and the high level of government spending, volunteering within the fields of social services $(3.3 \%)$ and education $(2.5 \%)$ is relatively low in comparison with the USA.

Measures. For measuring the hierarchical status of positions, the respondents were asked to classify their voluntary engagement as either core operative, supportive/ administrative, or leadership. The leadership-category contains both supervisory and board positions. We recoded this variable into to a binary one, meaning that in the regression models (Tables 4, 5, and 6) volunteers with at least one leadership position are coded as (1) and those without a senior/managerial position are coded as (0).

Educational status was measured through the highest level of educational qualification as an ordinal variable from 1 to 7. The Austrian Version of the NACE (Nomenclature statistique des activités économiques dans la Communauté européenne) and the ISCO 88 (International Standard Classification of Occupations) was used to indicate the occupational domains and the occupational status, and for further analyses, was allocated to the metric classification of ISEI. ${ }^{2}$

Logistic Regression. In order to explore the determinants associated with the hierarchical segregation of volunteers in Austria, our hypothesis was tested through the use of bivariate and multivariate analyses, especially logistic regression models (Pampel 2000; Mood 2010).

\section{Findings}

In Austria, the factors that shape formal volunteering are very similar to other OECD countries, which suggests the applicability of our findings to other countries (see Table 3). As previous research has shown (Brand 2010; Musick and Wilson 2008; Wilson 2012), education is important for voluntary engagement and is a significant predictor $\left(1.147^{* * * *}\right)$ for volunteering in Austria, too. In interaction with the other determinants, being in a paid job (1.070) does not increase the likelihood of volunteering. Homeownership is highly associated with volunteering $\left(1.444^{* * *}\right)$, though this can be interpreted in different ways, such as a proxy for wealth, stable residence, a higher stake in the local community, or for a rural residency (Rotolo et al. 2010). Being married is another independent predictor $\left(1.393^{* * *}\right)$ for volunteering. Females $\left(0.558^{* * *}\right)$ and immigrants $\left(0.521^{* * *}\right)$ have smaller chances to get involved in volunteering, compared to males and Austrian citizens, respectively.

\footnotetext{
${ }^{2}$ International Socio-Economic Index of Occupational Status.
} 
Table 3 Logistic regression: determinants of volunteering in Austria. Source: Austria Microcensus 2006/Q4

\begin{tabular}{ll}
\hline & Exp(B) \\
\hline Female (ref. male) & $.558^{* * *}$ \\
Age & $.990^{* * *}$ \\
Nationality (ref. Austrian) & $.521^{* * *}$ \\
Educational Level (1 to 8) & $1.147^{* * *}$ \\
Employed (ref. Not Employed, Jobless, Retired, Home maker; Student) & 1.070 \\
Homeownership (ref. rental/else) & $1.444^{* * *}$ \\
Married (ref. unmarried, divorced, widowed) & $1.393^{* * *}$ \\
Population density & $.737^{* * *}$ \\
Intercept & $3.667^{* * *}$ \\
$N$ & 11,657 \\
Chi ${ }^{2} / \mathrm{d} f$ & $906 / 8$ \\
-2 Log-Likelihood & $14,899.3$ \\
Pseudo $R^{2}$ (Nagelkerke's) & .101 \\
\hline$p<.05 ; p<.01 ; p<.01$
\end{tabular}

${ }^{*} p<.05 ;{ }^{* *} p<.01 ;{ }^{* * *} p<.001$

Table 4 Descriptive characteristics of volunteers in senior/managerial positions in the four fields in comparison with the Austrian Population. Source: Austria Micro-census 2006/Q4

\begin{tabular}{|c|c|c|c|c|c|}
\hline \multirow[t]{2}{*}{ Characteristics } & \multicolumn{5}{|c|}{ Senior/managerial positions (Volunteering) } \\
\hline & $\begin{array}{l}\text { Sports } \\
(n=264)\end{array}$ & $\begin{array}{l}\text { Politics } \\
(n=221)\end{array}$ & $\begin{array}{l}\text { Religion } \\
(n=179)\end{array}$ & $\begin{array}{l}\text { Social } \\
\text { Services } \\
(n=125)\end{array}$ & $\begin{array}{l}\text { Austrian } \\
\text { Population } \\
(n=41,412)\end{array}$ \\
\hline $\begin{array}{l}\text { Age of volunteers in senior/managerial position: Mean } \\
(S D)^{\mathrm{a}}\end{array}$ & $46.21(12.25)$ & $\begin{array}{l}47.05 \\
\quad(12.07)\end{array}$ & $47.98(14.24)$ & $\begin{array}{r}51.23^{* * *} \\
(15.14)\end{array}$ & $46.07(18.70)$ \\
\hline Education $^{\mathrm{b}}$ & $* * *$ & $* * *$ & $* * *$ & $* * *$ & \\
\hline 1 No diploma or primary school diploma & $4.9 \%$ & $5.4 \%$ & $10.1 \%$ & $7.2 \%$ & $27.7 \%$ \\
\hline 2 Apprenticeship certificate & $42.4 \%$ & $35.7 \%$ & $21.2 \%$ & $29.6 \%$ & $35.9 \%$ \\
\hline 3 Intermediate technical and vocational diploma & $13.6 \%$ & $19.5 \%$ & $19.6 \%$ & $15.2 \%$ & $12.7 \%$ \\
\hline 4 Secondary diploma & $6.1 \%$ & $8.1 \%$ & $8.4 \%$ & $5.6 \%$ & $6.3 \%$ \\
\hline 5 Technical and vocational secondary diploma & $14.0 \%$ & $11.3 \%$ & $11.2 \%$ & $11.2 \%$ & $7.9 \%$ \\
\hline 6 Post-secondary non-tertiary diploma & $4.9 \%$ & $7.2 \%$ & $8.9 \%$ & $8.8 \%$ & $1.8 \%$ \\
\hline 7 University diploma & $14.0 \%$ & $12.7 \%$ & $20.7 \%$ & $22.4 \%$ & $7.8 \%$ \\
\hline $\begin{array}{l}\text { ISEI of employed volunteers in senior/managerial } \\
\text { positions }{ }^{\mathrm{a}} \text { (min. } 16, \text { max. } 90 \text { score): Mean }(S D)\end{array}$ & $49.74^{* * * *}(15.93)$ & $\begin{array}{r}47.10^{* * *} \\
(17.65)\end{array}$ & $49.38^{* * *}(16.95)$ & $\begin{array}{r}55.49^{* * *} \\
(15.90)\end{array}$ & $42.05(15.91)$ \\
\hline Occupation $^{\mathrm{b}}$ & $* * *$ & $* * *$ & $* * *$ & $* * *$ & \\
\hline $\begin{array}{l}\text { Economically inactive (jobless, retired, home makers, } \\
\text { students) }\end{array}$ & $20.8 \%$ & $14.9 \%$ & $34.6 \%$ & $46.4 \%$ & $51.8 \%$ \\
\hline Manual & $23.1 \%$ & $16.4 \%$ & $9.6 \%$ & $8.0 \%$ & $19.2 \%$ \\
\hline Farmer & $.8 \%$ & $9.1 \%$ & $4.5 \%$ & - & $2.0 \%$ \\
\hline Non-manual & $46.0 \%$ & $46.6 \%$ & $43.7 \%$ & $32.0 \%$ & $20.8 \%$ \\
\hline Self-employed & $8.3 \%$ & $12.7 \%$ & $6.2 \%$ & $13.6 \%$ & $4.4 \%$ \\
\hline Other (e.g., in apprenticeship) & $1.1 \%$ & $.5 \%$ & $1.7 \%$ & - & $2.0 \%$ \\
\hline
\end{tabular}

Testing for differences between the volunteers and the Austrian population (age $\geq 15 \mathrm{y}$ )

${ }^{\mathrm{a}} t$ test

${ }^{\mathrm{b}}$ Chi-squared test

${ }^{*} p<.05 ;{ }^{* *} p<.01 ;{ }^{* * *} p<.001$

Table 4 shows the characteristics of leading volunteers in the four selected fields. Their average age is similar to the average age of the Austrian population over 15 years
(46.07) in the fields of sport (46.21), politics (47.05), and religion (47.98). Only in social services are volunteers in senior/managerial positions $\left(51.23^{* * *}\right)$ significantly older 
than the average population (46.07). People with the lowest educational status are significantly underrepresented in senior/managerial positions in all four fields, whereas people with post-secondary and tertiary diplomas are overrepresented, especially in the field of religion (12.9\%), and social services $(+14.6 \%)$.

Paid work matters (Marshall and Taniguchi 2012; Webb and Abzug 2008). In all four fields, the occupational status (ISEI) of volunteers in senior/managerial positions $\left(49.74^{* * *}, 47.10^{* * *}, 49.38^{* * *}\right.$, and $\left.55.49^{* * *}\right)$ is significantly higher in comparison with the Austrian population (42.05). With the exception of the social services field, employment itself is strongly related to having a senior/managerial position within the volunteering sector (Table 4, Strauß 2008). Intermediate and higher ranks as well as professional occupations, executives, and the self-employed are overrepresented in senior/managerial positions in all four fields, whereas farmers "in charge" are only overrepresented in the field of politics $(+7.1 \%)$ and religion $(+2.5 \%)$.

\section{Senior/Managerial Positions}

The logistic regression models ${ }^{3}$ (Tables 5 and 6) indicate that occupational and educational status independently and significantly affect the hierarchization of voluntary positions. Gender as well as age are significant, too. This mirrors gender and age stereotypes as well as the hierarchical segregation in most business career fields (Mayrhofer et al. 2008). A higher occupational status in paid work contributes $\left(1.010^{* * *}\right)$ to gaining a senior/managerial position in volunteering. An increase of one score on the ISEI scale (min. 16, max. 90 score) increases the probability of getting into a senior/managerial position in volunteering by $1 \%$. Compared to males, females' likelihood to be in charge $\left(0.391^{* * * *}\right)$ is reduced to $60.9 \%$. Likewise, educational status increases the chance to be in a senior/managerial position by $12.8 \%$ by each step further on the educational ladder. Therefore, $\mathrm{H}_{1}, \mathrm{H}_{2}$, and $\mathrm{H}_{3}$ are strongly supported. For men (see Table 6), age is a significant predictor $\left(1.015^{* * *}\right)$ for senior/managerial positions. In contrast, age does not significantly increase the likelihood for females (1.007). Due to the impossibility of testing for the significance of differences between odds ratios of two different subgroups, we cannot support or reject our hypothesis $\left(\mathrm{H}_{4}\right)$ on gender-differences. The odds ratios (see Table 6) indicate that senior/managerial positions relate with occupational status similarly for females

\footnotetext{
3 The explanatory power (Nagelkerke's Pseudo $\mathrm{R}^{2}$ ) of the models ranges between $2 \%$ and $8 \%$. Those low $\mathrm{R}^{2}$ values are due to the fact that we build up our models for the purpose of testing the significance of four chosen factors (age, gender, occupation, education) instead of optimizing explanatory power of the full models.
}

$\left(1.007^{* *}\right)$ and males $\left(1.012^{* * *}\right)$. Yet for females, educational status relates more strongly $\left(1.210^{* * *}\right)$ with senior/managerial positions than for males $\left(1.085^{* * *}\right)$.

\section{Field-Specific Analysis}

Occupational status significantly relates to senior/managerial positions in the field of sports and politics, but not in the fields of religion and social services. With an odds ratio of $1.016^{* * *}$, each step on the occupational status scale (ISEI) significantly raises higher probability in sports by $1.6 \%$. Therefore, we have to reject $\mathrm{H}_{1 \text {-sport }}$. Following our hypothesis $\mathrm{H}_{1 \text {-politics, occupational status also increases }}$ $\left(1.019^{* * *}\right)$ the probability of getting into senior/managerial positions in politics. With an odds ratio of $1.000 \mathrm{H} 1_{\text {religion }}$ has to be supported, and $\mathrm{H}_{1 \text {-social }}(0.998)$ has to be rejected, revealing that there is no spillover of occupational status in religion or in social services.

Educational status significantly increases the chance of holding a senior/managerial position in the field of religion $\left(1.268^{* * *}\right)$ and social services $\left(1.284^{* * * *}\right)$. Each increase in educational status by one-step increases the probability to be in charge by $26.8 \%$ (religion) or even $28.4 \%$ (social services). Therefore, $\mathrm{H}_{2 \text {-religion }}$ and $\mathrm{H}_{2 \text {-social }}$ are supported by our data. In sports and politics, however, the educational status does not raise the probability of holding a senior/managerial position. Thus, we reject $\mathrm{H}_{2 \text {-sport }}$ and $\mathrm{H}_{2}$ politics.

Gender also has a significant impact. Females have less chances to get into senior/managerial positions in sports $\left(0.391^{* * *}\right)$, politics $\left(0.191^{* * *}\right)$, and even in social services $\left(0.675^{*}\right)$. In religion, males and females have similar chances to be in a senior/managerial position. Thus, our analyses support $\mathrm{H}_{3 \text {-sport }}, \mathrm{H}_{3 \text {-politics }}$, and $\mathrm{H}_{3 \text {-religion, but reject }}$ $\mathrm{H}_{3 \text { - social. }}$.

Field-specific findings on spillover-effects of occupational status in sports (males: 1.015, females: 1.021) and politics (males: 1.017, females: 1.025) point in the same direction for both genders. The differences in the odds ratios of males and females are marginal (see Table 6).

Likewise, we found no gender-specific spillover-effects in religion (males: 0.999; females: 1.002) and social services (males: 1.001, females: 0.994). The impact of educational status does not differ, either, between genders. Though we cannot directly test for differences in odds ratios, these findings suggest support our gender-specific hypotheses $\mathrm{H}_{4 \text {-sport }}$ and $\mathrm{H}_{4 \text {-politics }}$, but rather reject $\mathrm{H}_{4 \text {-religion }}$ and $\mathrm{H}_{4 \text {-social }}$.

In summary, we found direct occupational spillovereffects in the fields of sports and politics, and educational effects in the fields of religion and social services. Finally, we found gender effects in all fields except religion. 
Table 5 Logistic regression: senior/managerial position in volunteering. Source: Austria Micro-census 2006/Q4

\begin{tabular}{|c|c|c|c|c|c|}
\hline & $\begin{array}{l}\text { Model-I } \\
\text { Total } \\
\operatorname{Exp}(\mathrm{B})\end{array}$ & $\begin{array}{l}\text { Model-II } \\
\text { Sports } \\
\text { Exp(B) }\end{array}$ & $\begin{array}{l}\text { Model-III } \\
\text { Politics } \\
\text { Exp(B) }\end{array}$ & $\begin{array}{l}\text { Model-IV } \\
\text { Religion } \\
\text { Exp(B) }\end{array}$ & $\begin{array}{l}\text { Model } \\
\text { Social services } \\
\operatorname{Exp}(B)\end{array}$ \\
\hline Female & $.391^{* * *}$ & $.191^{* * * *}$ & $.244^{* * *}$ & 1.209 & $.675^{*}$ \\
\hline Age & $1.011^{* * *}$ & $1.015^{* * *}$ & $1.020^{* * *}$ & $1.015^{* *}$ & $1.027^{* * *}$ \\
\hline Educational status ( 1 to 7 ) & $1.128^{* * *}$ & 1.046 & 1.041 & $1.268^{* * *}$ & $1.284^{* * *}$ \\
\hline Occupational status (ISEI) & $1.010^{* * *}$ & $1.016^{* * *}$ & $1.019^{* * *}$ & 1.000 & .998 \\
\hline Intercept & $.138^{* * *}$ & $.054^{* * * *}$ & $.024^{* * *}$ & $.003^{* * *}$ & $.002^{* * * *}$ \\
\hline$n$ (senior/managerial volunteers in the specific field) & 1,288 & 264 & 221 & 179 & 125 \\
\hline$n$ ref. group (all other volunteers and non-volunteers in the overall sample) & 10,369 & 11,393 & 11,436 & 11,478 & 11,532 \\
\hline$C h i^{2} / d f$ & $498 / 4$ & $204 / 4$ & $161 / 4$ & $65 / 4$ & $68 / 4$ \\
\hline -2 Log-Likelihood & 7604.59 & 2317.77 & 2029.634 & 1785.044 & 1314.396 \\
\hline Pseudo $R^{2}$ (Nagelkerke's) & .08 & .09 & .08 & .04 & .05 \\
\hline
\end{tabular}

${ }^{*} p<.05 ;{ }^{* *} p<.01 ;{ }^{* * *} p<.001$

Table 6 Gender-specific contrast or spillover: logistic regression: senior/managerial position in volunteering. Source: Austria Micro-census 2006/Q4

\begin{tabular}{|c|c|c|c|c|c|c|c|c|c|c|}
\hline & \multirow{2}{*}{\multicolumn{2}{|c|}{$\frac{\text { Total }}{\operatorname{Exp}(B)}$}} & \multirow{2}{*}{\multicolumn{2}{|c|}{$\frac{\text { Sport }}{\operatorname{Exp}(B)}$}} & \multirow{2}{*}{\multicolumn{2}{|c|}{$\frac{\text { Politics }}{\operatorname{Exp}(B)}$}} & \multirow{2}{*}{\multicolumn{2}{|c|}{$\frac{\text { Religion }}{\operatorname{Exp}(\mathrm{B})}$}} & \multirow{2}{*}{\multicolumn{2}{|c|}{$\begin{array}{l}\text { Social Services } \\
\operatorname{Exp}(B)\end{array}$}} \\
\hline & & & & & & & & & & \\
\hline & Male & Female & Male & Female & Male & Female & Male & Female & Male & Female \\
\hline Age (in years) & $1.015^{* * *}$ & 1.007 & $1.015^{* *}$ & 1.015 & $1.022^{* * *}$ & 1.015 & $1.018^{*}$ & 1.013 & $1.032^{* * *}$ & $1.021^{*}$ \\
\hline $\begin{array}{l}\text { Highest level of education ( } 1 \\
\text { to } 7 \text { ) }\end{array}$ & $1.085^{* * * *}$ & $1.210^{* * * *}$ & 1.034 & 1.098 & 1.044 & 1.017 & $1.300^{* * *}$ & $1.234^{* * * *}$ & $1.258^{* * *}$ & $1.312^{* * *}$ \\
\hline Occupational Status (ISEI) & $1.012^{* * *}$ & $1.007^{* *}$ & $1.015^{* * *}$ & $1.021^{* *}$ & $1.017^{* * *}$ & $1.025^{* *}$ & .999 & 1.002 & 1.001 & .994 \\
\hline Intercept & $.050^{* * *}$ & $.022^{* * *}$ & $.011^{* * *}$ & $.001^{* * * *}$ & $.006^{* * *}$ & $.002^{* * *}$ & $.002^{* * *}$ & $.004^{* * * *}$ & $.001^{* * * *}$ & $.001^{* * * *}$ \\
\hline $\begin{array}{l}n \text { (senior/managerial } \\
\text { volunteers in the specific } \\
\text { field) }\end{array}$ & 884 & 404 & 220 & 44 & 177 & 44 & 79 & 100 & 73 & 52 \\
\hline $\begin{array}{l}n \text { ref. group (all other } \\
\text { volunteers and non- } \\
\text { volunteers in the overall } \\
\text { sample) }\end{array}$ & 4,616 & 5,751 & 5,282 & 6,111 & 5,324 & 6,111 & 5,423 & 6,055 & 5,429 & 6,103 \\
\hline $\mathrm{Chi}^{2} / \mathrm{df}$ & $134 / 3$ & $109 / 3$ & $37 / 3$ & $18 / 3$ & $44 / 3$ & $15 / 3$ & $40 / 3$ & $26 / 3$ & $42 / 3$ & $21 / 3$ \\
\hline -2 Log-Likelihood & 4716.24 & 2872.39 & 1810.31 & 504.94 & 1520.637 & 507.296 & 787.541 & 996.566 & 734.151 & 579.13 \\
\hline Pseudo $R^{2}$ (Nagelkerke's) & .04 & .05 & .02 & .03 & .03 & .03 & .05 & .03 & .06 & .04 \\
\hline
\end{tabular}

${ }^{*} p<.05 ;{ }^{* *} p<.01 ;{ }^{* * *} p<.001$

\section{Discussion}

Our study contributes a more fine-grained analysis of four different fields of volunteering, and shows that spillovereffects dominate volunteering, not only in general, but also in sports, politics, religion, and social services. We did not find any empirical support for a contrast-effect hypothesis. Obviously, resources and reputation acquired previously in other fields is crucial for advancement in volunteering, and the field of volunteering rather mirrors and replicates economic and societal inequalities.

Yet we have also revealed remarkable differences between the fields of sports, politics, religion, and social services. Altogether, we have shown direct spillover-effects of occupational status in sports and politics, but not in religion and social services, in which educational status 
contributes to the chance of getting into senior/managerial positions. Men are much more likely to reach a senior/managerial position in sports, politics, and social services, but not in religion. Finally, we have found no evidence for extra-resources needed by females to get into senior/managerial positions in any field.

Revisiting the basic forces that might drive inequality in volunteering, we have confirmed one of the hypothesized spillover-effects of occupational status, namely in politics, but not in social services. For sports and politics, inequalities of paid work are widely transferred to volunteering (Diewald and Faist 2011). These similarities between sports and politics are perhaps typical for central European countries, as has been shown for Italy and the Czech Republic (Numerato and Baglioni 2012), where sports organizations bear some political characteristics and relate with politics in board-membership and careers in volunteering. Both fields favor males with higher occupational status for superior positions in volunteering.

Interestingly, there are no occupational spillover-effects in the two fields that are widely dominated by female volunteering, religion, and social services. This may also relate with the smaller share of economically active volunteers. As $39 \%$ (religion) and even $47 \%$ of all volunteers are out of paid employment, or in household, a relevant share of volunteers has a weak occupational status, which brings educational status to the foreground when it comes to advancement in volunteering. Furthermore, religion and social services are maybe more prone to education.

Yet they are not so prone to forward females. Only the field of religion seems to provide equal opportunities for female volunteers to get into senior/managerial positions. At first glance, it is surprising that the Catholic Church and its various CSOs still dominate the field of religion in Austria while not offering female access to priesthood. On closer examination, churches might compensate their gender discrimination in priesthood by including women in parish councils and similar boards. The higher number of women than men in Austria belonging to a particular religion might also have an effect.

We expected stronger spillover-effects in fields with larger organizations and a higher share of paid workforce, which was supported for politics but not for social services. We assume that volunteering in a social services CSO means working with highly vulnerable beneficiaries, which is often assumed to involve some form of "warm-glow" gratification from helping others, without yielding much prestige (Handy and Mook 2011). Furthermore, social services require capabilities such as ease of communication with marginalized groups, empathy, and care-giving. These capabilities do not relate with occupational status in other fields. Generally speaking, the adverse is also probable; the set of skills required for managerial positions may perhaps not be appropriate in the fields of elderly care and childcare. The tabooed symbolic exchange is maybe weakest in this field, i.e., volunteers in social services earn less symbolic capital and reputation. Social services is a field dominated by females that promises little reputational gains. However, effects of educational status and gender hinder social services from becoming a real egalitarian playground for alternative careers in volunteering.

We assumed that spillover-effects were stronger in maledominated fields and in fields with a higher percentage of employed volunteers (as opposed to the retired, homemakers, or others not in paid employment). This is the case in sports and politics. We further assumed stronger spillover-effects in fields with fewer senior/managerial positions, thus appealing to exclusivity. This assumption was not supported by our results, as we did not reveal direct spillover-effects in religion and social services. In these fields, it is less the occupational status but much more the educational status that shapes high-level careers in volunteering.

Although the male-dominated fields (sports and politics) widen the gender gap when it comes to senior/managerial positions, and although even in the female-dominated social services field males do have easier access to superior positions, we did not find any gender-differences in the requirement of occupational or educational status. This means that for volunteering in politics, sports, and social services women are disadvantaged in their advancement toward senior/managerial positions, and they cannot compensate for this disadvantage with a higher occupational or educational status.

Our study findings contribute to the discussion of stratification within different fields of volunteering. Until now, research has paid little attention to mechanisms that lead to hierarchical segregation and a lack of diversity in the voluntary sector. Prior research on ethnic, gender, and age segregation has focused on entry barriers. It neglected the meritocratic relations between cultural, economic, social, and symbolic capital, which is invested in volunteering, and yields different returns in other fields. We have referred to Pierre Bourdieu, who explains why these benefits and returns have to be tabooed by the illusio of the voluntary field (Bourdieu 1998, 76ff.). We suppose that fields like sports and politics convey symbolic capital more directly, thus also providing their leading volunteers with economic benefits. In religion and social services, the symbolic capital provided is much more specific and cannot be converted easily into economic advantages, at least not in continental Europe. This explains the strong spillovers in sports and politics, and the male dominance in these more prestigious fields. In a nutshell, "the long arm of the job" (Wilson and Musick 1997b) shapes volunteering in the fields of sports and politics, whereas the long arm 
of education shapes it in the fields of religion and social services.

\section{Implications and Limitations}

There are various implications of our study. Social elites do not only have superior qualities and quantities of resources at their disposal (capital endowment), they also have the power of designation, since elites influence how we perceive the social world and how we evaluate resources (Vogt 2005, 157). Unequal probabilities of reaching a senior/managerial position in volunteering therefore show that different groups have unequal chances of actualizing their interests in the voluntary sector and, in a broader sense, in civil society.

Aside from detailing our results, we hope to further progress the theoretical discussion surrounding volunteering. To date, resource theories (Wilson 2000) and status theories (Smith and Wang 2016) have provided competing explanations for the access to voluntary work (Qvist 2018). We expand on theory explaining inequalities and stratification within volunteering, and with Bourdieu's theory of practice, we offer a theoretical bridge between resourceand status-based approaches. In this theory, individual actors acquire resources (capital) that contribute to their status in various social fields. Next, this status signals resources for achieving executive positions in other fields as well, insofar as a status achieved in one field works as a resource in another field. Hence, there is a reinforcing process between capital and status, which constitutes the dynamics of the field. For instance, a successful businessperson who has gained reputation, i.e., symbolic capital, which is also valued in the field of volunteering also results in them taking a highly esteemed board position in a sports club. Also in Bourdieu's terms, this leads to an accumulation of capital, i.e., to the Matthew effect.

Our results reveal interesting differences: In politics and sports, there is a rather straightforward translation of occupational prestige into voluntary status. Of course, there may be very specific capital not covered by our study that is crucial. For instance, leading board members of sports organizations who have been successful athletes formerly, or volunteers in politics who come from strongly politicized families. Such nuanced capital and habitual predispositions for advancement in volunteering provide fertile ground for further research.

Whereas occupational status translates rather directly into social position in politics and sports, we found a subtler translation of cultural capital into status in the fields of religion and social services. In these fields, mechanisms discriminate less overtly against females, and rather hold education in higher esteem than mere occupational status.
Our findings indicate subtle distinctions in the styles of volunteering (Bourdieu 1984) that could provide a promising field for further research. As we have outlined above, altruism is the illusio of volunteering, as volunteers justify their engagement by their need to help others. Maybe this illusio is changing, and self-actualization will gradually replace altruism as the core delusion of volunteers, at least in particular fields (as has already been suggested by Thompson and Bono 1992, and Anderson and Moore 1978).

We also see implications for CSOs' volunteer management, volunteer agencies, and for policymaking. First, diversity management should be strengthened for volunteering. Organizations should, for instance, run special programs that lead to more diversity and promote, for example, women to senior/managerial positions. To align the managerial desire for the best volunteers with the civic endeavor to integrate underrepresented groups, we recommend to better analyze the potential of volunteers with regard to their professional and personal development. Furthermore, board positions should be for those who represent underrepresented stakeholders and not for those with the highest reputation (Vantilborgh et al. 2011). The CSOs that advocate for more justice, equal opportunities, and social inclusion should at least avoid discriminatory mechanisms in their own processes of recruitment and promotion of volunteers. Finally, policymakers are advised to be more cautious with promoting voluntary engagement as a measure against discrimination (e.g., for the elderly, for immigrants).

Our study suffers from a couple of limitations, the first of which being that there are many imperfections in our database. Although we are endowed with a large sample size that allows unique and detailed quantitative analyses of single fields, we could not collect data on income and wealth. Further, we would have appreciated a finer measurement of hierarchical status in volunteering, such as by distinguishing between board positions and executive positions. We also lack data on ethnic origin, as we only know from our data that individuals born abroad are broadly underrepresented in volunteering.

Furthermore, we only analyzed characteristics of volunteers and not how CSOs selected them due to specific requirements, as we lack any matching organizational data. It is not surprising that boards and committees consist of high-status individuals, as they are helpful in external governance (Maier and Meyer 2011) and for the managerialization of CSOs (Maier et al. 2016). Insofar, our data is rich on the individual level but lacks organizational requirements. Hence, we did not investigate mechanisms of inequality that are located on the organizational level and shaped, for example, by funding sources, governance structures, levels of professionalization, managerialization, 
and marketization. The structure and culture of CSOs should be investigated as a bottleneck and gatekeeper for volunteering, for example by their tendency toward homophily (e.g., Aksoy 2015; Ibarra 1992). Further research should also address this perspective, for instance, by qualitatively analyzing CSOs that do not conform with the usual spillover-effects of their field when they select their volunteers and promote them into senior/managerial positions.

Finally, the bridge between our guiding theory and the empirical analysis is narrow and shaky. For this study, the framework of Pierre Bourdieu provided us with inspiration and helped us in sense-making. Yet we admit that our data fit the theoretical concepts only in a rudimentary way, as our database lacks detailed information on volunteers' circumstances and capital endowment. Therefore, we strongly encourage further research to better utilize the richness of Pierre Bourdieu's concepts.

The underlying challenge that we could not untangle with our methodology was to find the interrelation between the levels of supply and demand in terms of the voluntary workforce. In this respect, causality is hard to reveal. Therefore, it either needs a multilevel longitudinal panel that tracks the interplay of individual and organizational factors, or a very fine-grained qualitative methodology that elaborates on this interplay. As an alternative, we found refuge in Bourdieu's theory that assumes a circularity between agency and structure, in our case between the individual characteristics, such as traits, capabilities and motivations, and the organizational demand. Therefore, we cannot safely blame either of these two sides for the inequalities present in volunteering. We are confident that we have revealed some underlying pattern in the fields of volunteering. We hope that our research encourages CSOs to further act against unfair exclusion and that it promotes an equal accessibility of attractive and powerful positions in volunteering.

Funding Open Access funding provided by Vienna University of Economics and Business (WU). The authors received no financial support for the research, authorship, and/or publication of this article.

\section{Compliance with Ethical Standards}

Conflict of interest The authors declared no potential conflicts of interest with respect to the research, authorship, and/or publication of this article.

Open Access This article is licensed under a Creative Commons Attribution 4.0 International License, which permits use, sharing, adaptation, distribution and reproduction in any medium or format, as long as you give appropriate credit to the original author(s) and the source, provide a link to the Creative Commons licence, and indicate if changes were made. The images or other third party material in this article are included in the article's Creative Commons licence, unless indicated otherwise in a credit line to the material. If material is not included in the article's Creative Commons licence and your intended use is not permitted by statutory regulation or exceeds the permitted use, you will need to obtain permission directly from the copyright holder. To view a copy of this licence, visit http://creativecommons. org/licenses/by/4.0/.

\section{References}

Aksoy, O. (2015). Effects of heterogeneity and homophily on cooperation. Social Psychology Quarterly, 78(4), 324-344.

Anderson, J. C., \& Moore, L. F. (1978). The motivation to volunteer. Journal of Voluntary Action Research, 7(3-4), 120-129.

Blau, P. M. (1977). Inequality and heterogeneity: A primitive theory of social structure. New York: The Free Press.

Bourdieu, P. (1977). Outline of a theory of practice. Cambridge: Cambridge University Press.

Bourdieu, P. (1984). Distinction: A social critique of the judgement of taste. Abingdon: Routledge.

Bourdieu, P. (1986a). Die biographische illusion. BIOS Zeitschrift für Biographieforschung und Oral History, 1, 75-81.

Bourdieu, P. (1986b). The forms of capital. In J. G. Richardson (Ed.), Handbook of theory and research for the sociology of education (pp. 241-258), New York.

Bourdieu, P. (1998). Practical reason: On the theory of action. Stanford: Stanford University Press.

Brady, H. E. (2003). An analytical perspective on participatory inequality and income inequality. A paper for the Russell Sage Foundation Project on the "Social Dimensions of Inequality". Russell Sage Foundation Working Paper Series.

Brand, J. E. (2010). Civic returns to higher education: A note on heterogeneous effects. Social Forces, 89(2), 417-434.

Broese van Groenou, M., \& van Tilburg, T. (2012). Six-year followup on volunteering in later life: A cohort comparison in the Netherlands. European Sociological Review, 28(1), 1-11.

Chacón, F., Gutiérrez, G., Sauto, V., Vecina, M. L., \& Pérez, A. (2017). Volunteer functions inventory: A systematic review. Psicothema, 29(3), 306-316.

Clary, E. G., Ridge, R. D., Stukas, A. A., Snyder, M., Copeland, J., Haugen, J., \& Miene, P. (1998). Understanding and assessing the motivations of volunteers: A functional approach. Journal of Personality and Social Psychology, 74(6), 1516-1530.

Diewald, M., \& Faist, T. (2011). From heterogeneities to inequalities: Looking at social mechanisms as an explanatory approach to the generation of social inequalities, SFB 882 Working Paper Series. Bielefeld: DFG Research Center.

Egerton, M. (2002). Higher education and civic engagement. British Journal of Sociology, 52(4), 603-620.

Federal Ministry of Labor, Social Affairs and Consumer Protection (2015). Bericht zur Lage und zu den Perspektiven des freiwilligen Engagements in Österreich. (2. Freiwilligenbericht). Wien: BMASK.

Fisher, R. J., \& Ackerman, D. (1998). The effects of recognition and group need on volunteerism: A social norm perspective. Journal of Consumer Research, 25(3), 262-275.

Galen, L. W., Sharp, M., \& McNulty, A. (2015). Nonreligious group factors versus religious belief in the prediction of prosociality. Social Indicators Research, 122(2), 411-432.

Grönlund, H. (2011). Identity and volunteering intertwined: Reflections on the values of young adults. VOLUNTAS: International Journal of Voluntary and Nonprofit Organizations, 22(4), 852-874.

Haberfeld, Y. (1992). Employment discrimination: An organizational model. Academy of Management Journal, 35, 161-180. 
Handy, F., Cnaan, R. A., Hustinx, L., Kang, C., Brudney, J. L., HaskiLeventhal, D., et al. (2010). A cross-cultural examination of student volunteering: Is it all about résumé building? Nonprofit and Voluntary Sector Quarterly, 39(3), 498-523.

Handy, F., \& Greenspan, I. (2009). Immigrant volunteering: A stepping stone to integration? Nonprofit and Voluntary Sector Quarterly, 38(6), 956-982.

Handy, F., \& Mook, L. (2011). Volunteering and volunteers: Benefitcost analyses. Research on Social Work Practice, 21, 412-420.

Hapke, Y. (2009). Identity and integration in Europe. Munich: AVM.

Hodgkinson, V. A. (2003). Volunteering in global perspective. In P. Dekker \& L. Halman (Eds.), The values of volunteering: Crosscultural perspectives (pp. 35-53). New York: Springer.

Hustinx, L. (2007). Brave new volunteers? The value of paid and unpaid work for Flemish red cross volunteers. VOLUNTAS: International Journal of Voluntary and Nonprofit Organizations, 18(1), 73-89.

Hustinx, L. (2010). I quit, therefore I am? Volunteer turnover and the politics of self-actualization. Nonprofit and Voluntary Sector Quarterly, 39(2), 236-255.

Hustinx, L., \& Handy, F. (2009). Where do I belong? Volunteer attachment in a complex organization. Administration in Social Work, 33(2), 202.

Hustinx, L., \& Lammertyn, F. (2003). Collective and reflexive styles of volunteering. A Sociological Modernization Perspective. VOLUNTAS: International Journal of Voluntary and Nonprofit Organizations, 14(2), 167-187.

Ibarra, H. (1992). Homophily and differential returns: Sex differences in network structure and access in an advertising firm. Administrative Science Quarterly, 37(3), 422-427.

Institute for Volunteering Research. (2004). Volunteering for all? Exploring the link between volunteering and social exclusion. London: Institute for Volunteering Research.

James, E. D., \& Rose-Ackermann, S. (1986). The nonprofit enterprise in market economics. Amsterdam: Harwood.

Landau, J. (1995). The relationship of race and gender to managers' ratings of promotion potential. Journal of Organizational Behavior, 16, 391-400.

Lazarsfeld, P., \& Merton, R. K. (1954). Friendship as a social process: A substantive and methodological analysis. In M. Berger, T. Abel, \& C. H. Page (Eds.), Freedom and control in modern society. New York: Van Nostrand.

Macmillan, R. (2013). 'Distinction' in the third sector. Voluntary Sector Review, 4(1), 39-54.

Maier, F., \& Meyer, M. (2011). Managerialism and beyond: Discourses of civil society organization and their governance implications. VOLUNTAS: International Journal of Voluntary and Nonprofit Organizations, 22(4), 731-756.

Maier, F., Meyer, M., \& Steinbereithner, M. (2016). Nonprofit organizations becoming business-like: A Systematic review. Nonprofit and the Voluntary Sector Quarterly, 45(1), 64-86.

Marshall, G. A., \& Taniguchi, H. (2012). Good jobs, good deeds: The gender-specific influences of job characteristics on volunteering. VOLUNTAS: International Journal of Voluntary and Nonprofit Organizations, 23, 213-235.

Mayrhofer, W., Meyer, M., Schiffinger, M., \& Schmidt, A. (2008). The influence of family responsibilities, career fields and gender on career success: An empirical study. Journal of Managerial Psychology, 23(3), 292-323.

McPherson, M., Smith-Lovin, L., \& Cook, J. M. (2001). Birds of a feather: Homophily in social networks. Annual Review of Sociology, 27, 415-444.

Melamed, D., Simpson, B., Harrell, A., Munn, C. W., Abernathy, J. Z., \& Sweitzer, M. (2020). Homophily and segregation in cooperative networks. American Journal of Sociology, 125(4), $1084-1127$.
Merino, S. M. (2012). Social resources and influence in religious networks: Consequences for social support, volunteering, and intergroup contact. Philadelphia: Pennsylvania State University.

Merino, S. M. (2013). Religious social networks and volunteering: Examining recruitment via close ties. Review of Religious Research, 55, 509-527.

Merton, R. K. (1968). The Matthew-effect in science. Science, 159(3810), 56-63.

Moen, P., Fields, V., Meador, R., \& Rosenblatt, H. (2000). Fostering integration: A case study of the Cornell Retirees Volunteering in Service (CRVIS) program.

Mood, C. (2010). Logistic regression: Why we cannot do what we think we can do, and what we can do about it. European Sociological Review, 26(1), 67-82.

Musick, M. A., \& Wilson, J. (2008). Volunteers: A social profile. Bloomington: Indiana University Press.

Neumayr, M., Pennerstorfer, A., Vandor, P., \& Meyer, M. (2017). Country report: Austria. In P. Vandor, N. Traxler, R. Millner, \& M. Meyer (Eds.), Civil society in central and eastern Europe: Challenges and opportunities. Vienna: ERSTE Foundation.

Neumayr, M., Schneider, U., Meyer, M., \& Haider, A. (2007). The NonprofitSector in Austria. An economic, legal und political appraisal, Vol. 01/2007. Working Papers Institut für Sozialpolitik, WU Vienna University of Economics and Business.

Nisbett, R. E., \& Wilson, T. D. (1977). The halo effect: Evidence for unconscious alteration of judgments. Journal of Personality and Social Psychology, 35(4), 250-256.

Numerato, D., \& Baglioni, S. (2012). The dark side of social capital: An ethnography of sport governance. International Review for the Sociology of Sport, 47(5), 594-611.

Ostrower, F. (2002). Trustees of culture: Power, wealth, and status on elite arts boards. Chicago: The University of Chicago Press.

Pampel, F. C. (2000). Logistic regression: A primer. Thousand Oaks: Sage.

Pearce, J. L. (1993). Volunteers. Mackays of Chatham PLC, Chatham: The organizational behaviour of unpaid workers.

Pfeffer, J., Davis-Blake, A., \& Julius, D. J. (1995). AA officer salaries and managerial diversity: Efficiency wages or status? Industrial Relations. A Journal of Economy and Society, 34(1), 73-94.

Quinn, K. (2020). Inside the penal voluntary sector: Divided discourses of "helping" criminalized women. Punishment \& Society, 22(2), 161-180.

Qvist, H. -P. Y. (2018). Individual and Social resources as causes and benefits of volunteering: Evidence from Scandinavia. Aalborg: Aalborg University.

Rigney, D. (2010). The Matthew effect: How advantage begets further advantage. New York: Columbia University Press.

Rotolo, T., \& Wharton, A. S. (2003). Living across institutions: Exploring sex-based homophily in occupations and voluntary groups. Sociological Perspectives, 46(1), 59-82.

Rotolo, T., \& Wilson, J. (2007). Sex segregation in voluntary work. The Sociological Quarterly, 48, 559-585.

Rotolo, T., Wilson, J., \& Hughes, M. E. (2010). Homeownership and volunteering: An Alternative approach to studying social inequality and civic engagement. Sociological Forum, 25(3), 570-587.

Ruiter, S., \& De Graaf, N. D. (2009). Socio-economic payoffs of voluntary association involvement: A Dutch life course study. European Sociological Review, 25(4), 425-442.

Salamon, L. M., \& Anheier, H. K. (1996). The international classification of nonprofit organizations: ICNPO-Revision 1, 1996. Baltimore: Johns Hopkins University Institute for Policy Studies.

Schlesinger, T., \& Gubler, R. (2016). Motivational profiles of sporting event volunteers. Sport in Society, 19(10), 1419-1439. 
Shachar, I. Y. (2014). The white management of 'volunteering': Ethnographic evidence from an Israeli NGO. VOLUNTAS: International Journal of Voluntary and Nonprofit Organizations, 25(6), 1417-1440.

Small, M. L. (2009). Unanticipated gains: Origins of network inequality in everyday life. Oxford: Oxford University Press.

Smith, D. H. (1994). Determinants of voluntary association participation and volunteering: A literature review. Nonprofit and Voluntary Sector Quarterly, 23, 243-263.

Smith, D. H., \& Wang, L. (2016). Conducive social roles and demographics influencing volunteering, The Palgrave handbook of volunteering, civic participation, and nonprofit associations. New York: Springer.

Spence, M. (1973). Job market signaling. Quarterly Journal of Economics, 90, 1-23.

Stebbins, R. A. (1996). Volunteering: A serious leisure perspective. Nonprofit and voluntary sector quarterly, 25(2), 211-224.

Stebbins, R. A. (2009). Would you volunteer? Society, 46(2), $155-159$.

Strauß, S. (2008). Volunteering and social inclusion: Interrelations between unemployment and civic engagement in Germany and Great Britain (1. ed.), VS Publisher (Verlag für Sozialwissenschaften), Wiesbaden.

Tang, F. (2006). What resources are needed for volunteerism? A life course perspective. The Journal of Applied Gerontology, 25(5), $375-390$.

Tharenou, P., \& Conroy, D. (1994). Men and women managers' advancement: Personal or situational determinants. Applied Psychology, 43(1), 5-31.

Therborn, G. (Ed.). (2006). Inequalities of the world. New theoretical frameworks, multiple empirical approaches (1 (publ). London: Verso.

Thompson, A. M., \& Bono, B. A. (1992). Alienation, self-actualization and the motivation for volunteer labor. Review of Radical Political Economics, 24(2), 115-123.

Tolsma, J., van der Meer, T. \& Gesthuizen, M. (2009). The impact of neighbourhood and municipality characteristics on social cohesion in the Netherlands. Acta Politica, 44(3), 286-313.

Unruh, D. R. (1979). Characteristics and types of participation in social worlds. Symbolic Interaction, 2(2), 115-130.

Unruh, D. R. (1980). The nature of social worlds. Pacific Sociological Review, 23(3), 271-296.
Van Ingen, E. (2009). Let's come together and unite: Studies of the changing character of voluntary association participation. Tilburg: Tilburg University.

Van Ingen, E., \& Dekker, P. (2010). Changes in the determinants of volunteering: Participation and time investment between 1975 and 2005 in the Netherlands. Nonprofit and Voluntary Sector Quarterly, 40(4), 682-702.

Vantilborgh, T., Bidee, J., Pepermans, R., Willems, J., Huybrechts, G., \& Jegers, M. (2011). A new deal for NPO governance and management: Implications for volunteers using psychological contract theory. VOLUNTAS: International Journal of Voluntary and Nonprofit Organizations, 22(4), 639-657.

Vogt, L. (2005). Das Kapital der Bürger. Theorie und Praxis zivilgesellschaftlichen Engagements, Campus, Frankfurt/Main u.a.

Webb, J. N., \& Abzug, R. (2008). Do occupational group members vary in volunteering activity? Nonprofit and Voluntary Sector Quarterly, 37(4), 689-708.

Weber, M. (1921/1980). Wirtschaft und Gesellschaft. Grundriss einer verstehenden Soziologie, J.C.B. Mohr (Paul Siebeck), Tübingen.

Weber, M. (1978). Economy and society: An outline of interpretive sociology. Berkeley: University of California Press.

Wetzel, C. G., Wilson, T. D., \& Kort, J. (1981). The halo effect revisited: Forewarned is not forearmed. Journal of Experimental Social Psychology, 17(4), 427-439.

Wilson, J. (2000). Volunteering. Annual Review of Sociology, 26, 215-240.

Wilson, J. (2012). Volunteerism research: A review essay. Nonprofit and Voluntary Sector Quarterly, 41(2), 176.

Wilson, J., \& Musick, M. A. (1997a). Who cares? Toward an integrated theory of volunteer work. American Sociological Review, 62, 694-713.

Wilson, J., \& Musick, M. A. (1997). Work and volunteering: The long arm of the job. Social Forces, 76(1), 251-272.

Zietsma, C., Groenewegen, P., Logue, D. M., \& Hinings, C. R. (2017). Field or fields? Building the scaffolding for cumulation of research on institutional fields. Academy of Management Annals, 11(1), 391-450.

Publisher's Note Springer Nature remains neutral with regard to jurisdictional claims in published maps and institutional affiliations. 